\title{
Geology of the
}

\section{Tintic Junction Quadrangle}

Tooele, Juab, and Utah

\section{Counties, Utah}

By HAL T. MORRIS

ZONTRIBUTIONS TO ECONOMIC GEOLOGY

GE OL O I C A L S U R V E Y B U L L E T I N $1142-\mathrm{L}$

A study of parts of the Tintic and

North Tintic mining districts

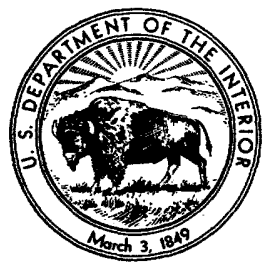


UNITED STATES DEPARTMENT OF THE INTERIOR

STEWART L. UDALL, Secretary

\author{
GEOLOGIGAL SURVEY
}

Thomas B. Nolan, Director

For sate by the Superintendent of Documents, U.S. Government Printing Office 


\section{CONTENTS}

\begin{tabular}{|c|c|}
\hline & $\begin{array}{r}\text { Page } \\
\text { L1 }\end{array}$ \\
\hline 年 & 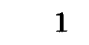 \\
\hline Rocks_- & \\
\hline (n- & \\
\hline Folds & 10 \\
\hline Thrust faults & 10 \\
\hline Transcurrent faults & 11 \\
\hline Tintic Prince fault & 11 \\
\hline Paxman fault $\ldots$ & 2 \\
\hline Beck fault & 3 \\
\hline Centennial fault & 13 \\
\hline Black Canyon fault & 14 \\
\hline Miners Canyon fault & 14 \\
\hline New Bullion fault & 14 \\
\hline Fremont fault & 15 \\
\hline ultt_-(- & 15 \\
\hline Lind fault $\ldots$ & 16 \\
\hline i fault & 16 \\
\hline Nassau fault & 16 \\
\hline fault & 17 \\
\hline al faults & 17 \\
\hline neralized faults and fissures & 18 \\
\hline al faults & 18 \\
\hline Mineral deposits & 19 \\
\hline Veins & 19 \\
\hline deposits & 22 \\
\hline posits & 22 \\
\hline & \\
\hline
\end{tabular}

\section{ILLUSTRATION}

Plate 1. Geologic map and section of the Tintic Junction quadrangle, Juab, Tooele, and Utah Counties, Utah............ In pocket

\section{TABLE}

TABLE 1. Generalized section of strata 



\title{
CONTRIBUTIONS TO ECONOMIC GEOLOGY
}

\section{GEOLOGY OF THE TINTIC JUNCTION QUADRANGLE, TOOELE, JUAB, AND UTAH COUNTIES, UTAH}

\author{
By Hax T. Morris
}

ABSTRACT

The Tintic Junction quadrangle covers about 57 square miles in Tintic Valley and in an adjacent part of the central East Tintic Mountains in west-central Utah. It includes mines and prospects that are in the northwestern part of the Tintic mining district and the southwestern part of the North Tintic mining district.

The rocks exposed in the quadrangle include quartzites and argillites of late Precambrian age; miogeosynclinal deposits (chiefly carbonate rocks) of Cambrian to Mississippian age; quartz latite, monzonite, and quartz monzonite of middle Eocene age; lacustrine and valley-fill deposits of Pliocene age; and colluvium, alluvium, and fanglomerate of Quaternary and Recent age.

The Precambrian and Paleozoic rocks, which are exposed at the crest and on the limbs of a large north-trending anticline, are cut by transcurrent faults of large displacement and by several associated minor thrust faults. Large normal faults include an east-trending tension fault that is older than the Tertiary lavas and a much younger north- to northwest-trending Basin and Range fault of large displacement that defines at least part of the western edge of the East Tintic Mountains. The intrusive rocks are cut by short north- and northeast-trending mineralized faults of small displacement that are probably just slightly younger than the igneous rocks.

The ore deposits in the quadrangle include narrow veins of high-grade argentiferons lead ore, chiefly in the intrusive stocks, and scattered small replacement deposits containing copper, lead, manganese, and other ores, chiefly in limestone and dolomite. High-silica quartzite has been quarried for ganister; large reserves of this rock are present.

\section{INTRODUCTION}

The Tintic Junction quadrangle is in the east-central part of the Basin and Range physiographic province about 20 miles west of the point where the boundary between the Colorado Plateaus and Middle Rocky Mountains provinces intersects the boundary of the Great Basin at the Wasatch fault. The quadrangle includes the west-central edge of the East Tintic Mountains, a fault-block range, and the northeastern part of Tintic Valley. 
The climate of the quadrangle area is semiarid. All streams are intermittent and drain into Tanner Creek, which empties into the Sevier River south of the adjoining Tintic Valley quadrangle. The vegetation is typical of the middle to high desert areas of the western conterminous United States and is characterized by sagebrush (Artemisia), rabbit brush (Chrysothamnus), juniper (Juniperus utahensis and $J$. scopulorum, and piñon pine (Pinus edulis and $P$. monophylla).

The quadrangle is one of five contiguous quadrangles of the $71 / 2^{-}$ minute series that contain the principal productive mines of the Tintic, East Tintic, and North Tintic mining districts. It joins the Eureka quadrangle on the west, the Allens Ranch quadrangle on the southwest, the Boulter Peak quadrangle on the south, and the Tintic Mountain quadrangle on the northwest. The boundary between the Tintic and North Tintic mining districts in the Tintic Junction quadrangle extends eastward approximately through Round Knoll and Packard Peak; the East Tintic mining district is entirely within the Eureka quadrangle.

The greater part of the fieldwork in the Tintic Junction quadrangle was done from July to December 1956. A few days were also spent in the field during June 1957 and May 1958. Many local residents, mine operators, and mining geologists working in the East Tintic Mountains were helpful during the course of the investigation. Special acknowledgement is made of the cooperation of R. C. Gebhardt of the E. J. Longyear Co. and Douglas Cook and William Shepard of the Bear Creek Mining Co., who provided copies of geologic and topographic maps of a large area contiguous to Jenny Lind Canyon. Officials of the Chief Consolidated Mining Co. furnished data including maps of the 1,100-foot level of the Evans mine. C. A. Fitch, Sr., C. A. Fitch, Jr., H. J. Pitts, and Max T. Evans of this company were most helpful. Louis Monter, president of the Tintic Prince Mining Co., furnished information concerning the Tintic Prince mine and the Munding prospect and made available private reports prepared by R. E. Marsell, Raymond Wimber, and B. F. Stringham. Carl Fields of Eureka provided several topographic names as well as information concerning the Fields prospect, and Carl Wahlberg of Salt Lake City furnished assay reports and maps of the Golden Sunset adit.

T. S. Lovering, who has studied the East Tintic mining district in the Eureka quadrangle, and A. E. Disbrow, who has mapped the Boulter Peak quadrangle, have offered stimulating discussion concerning general features of the geology and ore deposits of the East Tintic Mountains. 


\section{ROCKS}

The rocks exposed in the Tintic Junction quadrangle include a wide variety of sedimentary rocks and extrustive and intrusive igneous rocks, ranging in age from Precambrian to Recent. The principal lithologic characteristics of these rocks are summarized in table 1 ; detailed descriptions and correlations are given in other reports (Lindgren and Loughlin, 1919, p. 22-70, 99-102; Morris, 1957, p. 3-40; Morris and Lovering, 1961)

TABLE 1.-Generalized Section of: Strata in the Tintic Junction Quadrangle

\begin{tabular}{|c|c|c|c|c|}
\hline System & Series & Formation & $\underset{\text { (feet) }}{\text { Thickness }}$ & Character \\
\hline \multirow{2}{*}{ 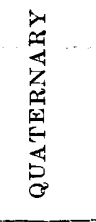 } & 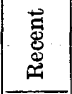 & Younger alluvium & $0-100+$ & $\begin{array}{l}\text { Silt, sand, and gravel younger than deposits } \\
\text { of Lake Bonneville group in adjoining } \\
\text { quadrangles. }\end{array}$ \\
\hline & 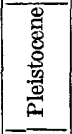 & Older alluvium & $0-500+$ & $\begin{array}{l}\text { Fanglomerate, talus, colluvium, and allu- } \\
\text { vium of early and middle Pleistocene (pre- } \\
\text { Lake Bonne ville) age. Includes upland } \\
\text { gravel and loess of late Pleistocene (Lake } \\
\text { Bonneville) age. }\end{array}$ \\
\hline \multirow{5}{*}{ 产 } & 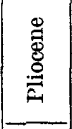 & Salt Lake(?) formation & $0-1,000+$ & $\begin{array}{l}\text { Marly limestone, bentonitic tuffaceous sedi- } \\
\text { ments, and gravel-streaked silt. In south- } \\
\text { western part of map area includes undif- } \\
\text { ferentiated patchy deposits of younger } \\
\text { pediment gravel. }\end{array}$ \\
\hline & \multirow{3}{*}{ 若 } & $\begin{array}{l}\text { Monzonite of the Silver } \\
\text { City stock }\end{array}$ & & $\begin{array}{l}\text { Medium- to light-gray, medium- to fine- } \\
\text { grained porphyritic monzonite; contains } \\
\text { andesine, orthoclase, biotite, augite, and } \\
\text { hornblende; xenoliths of quartzite common. } \\
\text { An intrusive body reportedly cut by work- } \\
\text { ings of Sacramento mine may be of similar } \\
\text { composition. }\end{array}$ \\
\hline & & $\begin{array}{l}\text { Swansea quartz monzo- } \\
\text { nite }\end{array}$ & & $\begin{array}{l}\text { Quartz monzonite of Swansea stock is me- } \\
\text { dium to light pinkish gray, medium to } \\
\text { fine graintd, porphyritic; contains sodic } \\
\text { andesine, orthoclase, quartz, and biotite. } \\
\text { Quartz monzonite of sill on Quartzite Ridge } \\
\text { contains large phenocrysts of andesine(?) } \\
\text { and water-clear quartz embedded in aph- } \\
\text { nitic matrix. All constituents except } \\
\text { quartz are replaced by argillic, propylitic, } \\
\text { and carbonate minerals. }\end{array}$ \\
\hline & & Unconformit & $0-1,500+$ & $\begin{array}{l}\text { Vitrophyre, flow rocks, and tuffs: } \\
\text { Vitrophyre, gray to black; phenocrysts } \\
\text { broken. } \\
\text { Flow rocks, pinkish- to bluish-gray, } \\
\text { medium-grained, porphyritic; unit con- } \\
\text { tains phenocrysts of andesine, sanidine, } \\
\text { quartz, and biotite in glassy to fine- } \\
\text { grained groundmass. } \\
\text { Tuffs, light-colored, fine-grained; vitric } \\
\text { and lithic. } \\
\text { Flow breccias mark tops of many vitro- } \\
\text { phyre and flow rock units. }\end{array}$ \\
\hline & 象兽 & Apex conglomerate & $0-300+$ & $\begin{array}{l}\text { Brick-red medium- to coarse-grained, poorly } \\
\text { bedded alluvial and colluvial deposits } \\
\text { below lavas. }\end{array}$ \\
\hline
\end{tabular}


TABLE 1.-Generalized Section of Strata in the Tintic Junction Quadrangle-Con.

\begin{tabular}{|c|c|c|c|c|}
\hline System & Series & Formation & $\begin{array}{l}\text { Thickness } \\
\text { (feet) }\end{array}$ & Character \\
\hline \multirow[b]{5}{*}{ 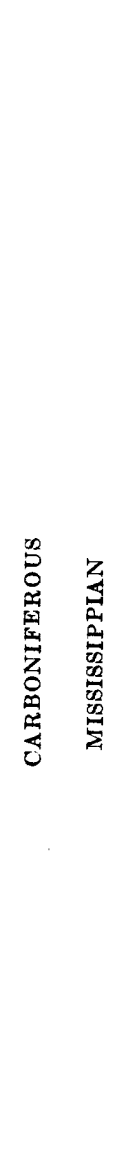 } & \multirow{3}{*}{ 善 } & Great Blue formation & 2,500 & $\begin{array}{l}\text { Chiefly blue-gray cherty limestone inter- } \\
\text { layered with olive-green shale and brown- } \\
\text { weathering limy quartzite in upper half of } \\
\text { exposed part. Only lower } 1,000 \text { ft or so of } \\
\text { formation is exposed in quadrangle. }\end{array}$ \\
\hline & & Humbug formation & 650 & $\begin{array}{l}\text { Alternating beds of light-gray limestone and } \\
\text { cross-bedded brown sandstone. }\end{array}$ \\
\hline & & Deseret limestone & $700-1,200$ & $\begin{array}{l}\text { Medium-gray cherty limestone interbedded } \\
\text { with brown-weathering sandy or shaly } \\
\text { limestone; many beds of limy sandstone in } \\
\text { upper half in northwestern part of quad- } \\
\text { rangle. }\end{array}$ \\
\hline & \multirow{3}{*}{ 营 } & Gardison limestone & $450-550$ & $\begin{array}{l}\text { Medium blue-gray well-bedded fossiliferous } \\
\text { limestone; upper two-thirds is medium to } \\
\text { coarse grained and cherty, especially upper } \\
125 \mathrm{ft} \text {; lower one-third is fine grained and } \\
\text { contains relatively little chert. }\end{array}$ \\
\hline & & Fitch ville formation & $275-300$ & $\begin{array}{l}\text { Eight distinctive units of limestone and } \\
\text { dolomite: } \\
\text { Curly limestone; distinctive bed of dense } \\
\text { medium- and dark-gray crenulated } \\
\text { limestone of algal origin; } 1.5 \text { ft. } \\
\text { Pink lithographic limestone; dense pink- } \\
\text { ish-gray limestone of high purity; } 7 \text { tt. } \\
\text { Sugary dolomite; medium- to dark-gray } \\
\text { medium-grained dolomite containing } \\
\text { one or more beds of novaculitic quartz- } \\
\text { its or, locally, green chert, } 10 \text { to } 20 \mathrm{ft} \\
\text { below top; } 58 \text { ft. } \\
\text { Black dolomite; dusky blue-gray to black } \\
\text { coarse-grained cherty dolomite; con- } \\
\text { spicuous almond-shaped pods of white } \\
\text { calcite and dolomite } 2 \text { to } 4 \text { in. long } \\
\text { replacing some of the chert nodules; } \\
65 \mathrm{ft} \text {. } \\
\text { Blue shaly limestone; blue-gray thin- } \\
\text { bedded fossiliferous limestone; } 46 \text { ft. } \\
\text { White limestone; massive coarse-grained } \\
\text { light-gray to white limestons; } 50 \mathrm{ft} . \\
\text { Blue flaky limestone; blue-gray thin- } \\
\text { bedded argillaceous limestone contain- } \\
\text { ing numerous small round flakes hav- } \\
\text { ing dark centers that are probably } \\
\text { fossil fragments; } 52 \text { ft. } \\
\text { Sand-grain marker bed; dull blue-gray } \\
\text { sand-streaked limestone or brownish- } \\
\text { weathering calcareous quartzite con- } \\
\text { taining rounded to ovoid grains of } \\
\text { frosted quartz from } 1 \text { mm to less than } \\
5 \text { mm in diameter; } 0.5 \text { ft, }\end{array}$ \\
\hline 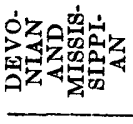 & & Pinyon Peak limestone & $70-300$ & $\begin{array}{l}\text { Medium to light blue-gray fine-grained lime- } \\
\text { stone; thin-and massive-bedded, silty; beds } \\
\text { of brown-weathering sandstone or shale } \\
\text { locally at base. }\end{array}$ \\
\hline 运 & 希 & & $125-300$ & $\begin{array}{l}\text { Medium-gray medium-bedded dolomite in- } \\
\text { terlayered with brown sandstone. }\end{array}$ \\
\hline 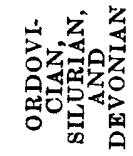 & & Bluebell dolomite & 600 & $\begin{array}{l}\text { Light-and dark-gray fine-and coarse-grained } \\
\text { medium- to massive-bedded dolomite; } 10 \text {-ft } \\
\text { bed of curly laminated dolomite about } 300 \\
\text { ft. above base. }\end{array}$ \\
\hline
\end{tabular}


TABLE 1.-Generalized Section of Strata in the Tintic Junction Quadrangle-Con.

\begin{tabular}{|c|c|c|c|c|}
\hline System & Series & Formation & $\begin{array}{c}\text { Thickness } \\
(\text { feet })\end{array}$ & Character \\
\hline \multirow{2}{*}{$\begin{array}{l}\text { Z } \\
\text { 芯 } \\
0 \\
0 \\
0 \\
0 \\
0 \\
0 \\
0 \\
0\end{array}$} & 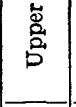 & Fish Haven dolomite & $270-350$ & $\begin{array}{l}\text { Dark-, medium-, and light-gray medium-and } \\
\text { coarse-grained massive- and thin-bedded } \\
\text { dolomite; bed of mottled cherty dolomite at } \\
\text { top. }\end{array}$ \\
\hline & 岁 & Opohonga limestone & $700-900$ & $\begin{array}{l}\text { Light blue-gray thin-bedded argillaceous } \\
\text { limestone; much flat-pebble conglomerate; } \\
\text { nodules of white chert in lower part, thin } \\
\text { unit of sandstone at base. }\end{array}$ \\
\hline \multirow{9}{*}{$\sum_{0}^{\frac{2}{4}}$} & \multirow[t]{2}{*}{ 总 } & Ajax dolomite & $555-660$ & $\begin{array}{l}\text { Three distinctive units of dolomite: } \\
\text { Upper member: medium- to dark-gray, } \\
\text { faintly mottled medium-bedded dolo- } \\
\text { mite; limy at top; much chert; about } \\
\text { 450 ft. } \\
\text { Emerald member: creamy white medium- } \\
\text { and coarse-grained massive dolomite; } \\
\text { not cherty; } 15-30 \text { ft. } \\
\text { Lower member: medium- to dark-gray } \\
\text { massive-bedded dolomite; moderately } \\
\text { cherty; } 90-180 \mathrm{ft} \text {. }\end{array}$ \\
\hline & & Opex formation & $140-350$ & $\begin{array}{l}\text { Limestone, shale, sandstone, and dolomite; } \\
\text { mostly thin bedded. }\end{array}$ \\
\hline & \multirow{6}{*}{$\stackrel{g}{g}$} & Cole Canyon dolomite & $830-900$ & $\begin{array}{l}\text { Altermating beds of Dagmar-type and Blue- } \\
\text { bird-type dolomite in units } 2-20 \mathrm{ft} \text { thick. } \\
\text { Dagmar-type beds sparse or absent near } \\
\text { top; formation is partly limestone in areas } \\
\text { remote from ore. }\end{array}$ \\
\hline & & Bluebird dolomite & $150-220$ & $\begin{array}{l}\text { Dusky blue-gray coarse-grained medium- to } \\
\text { massive-bedded dolomite studded with } \\
\text { small twig-shaped rods of white dolomite; } \\
\text { formation is partly or wholly limestone in } \\
\text { areas remote from ore. }\end{array}$ \\
\hline & & Herkimer limestone & $350-430$ & $\begin{array}{l}\text { Medium to light blue-gray fine-grained thin- } \\
\text { bedded limestone striped with red- and } \\
\text { yellow-weathering . mudstone; } 20 \text {-ft bed of } \\
\text { green shale } 180 \mathrm{ft} \text { above base. }\end{array}$ \\
\hline & & Dagmar dolomite & $60-100$ & $\begin{array}{l}\text { Light-gray to creamy-white fine-grained } \\
\text { laminated limy dolomite; forms conspicu- } \\
\text { ous marker bed. }\end{array}$ \\
\hline & & Teutonic limestone & 400 & $\begin{array}{l}\text { Medium to light blue-gray medium-and fine- } \\
\text { grained argillaceous limestone; some beds } \\
\text { pisolitic. }\end{array}$ \\
\hline & & Ophir formation & $295-\quad 430$ & $\begin{array}{l}\text { Distinctive, tripartite formation: } \\
\text { Upper member: gray-green sandy shale; } \\
35-90 \mathrm{ft} . \\
\text { Middle member: limestone and shale; } \\
\text { limestone is blue gray, argillaceous; } \\
\text { shale is gray green, fissile; 100-160 ft. } \\
\text { Lower member: gray-green fissile shale; } \\
\text { 6- to } 15 \text {-ft marker bed of blue limestone } \\
\text { or dusky-gray hydrothermal dolomite } \\
\text { 90 ft above base; base sandy; 160-180 ft. }\end{array}$ \\
\hline & 峁 & Tintic quartzite & $2,300-3,200$ & $\begin{array}{l}\text { White to buff medium-grained well-bedded } \\
\text { to massive quartzite; shaly at top, con- } \\
\text { glomeratic at base; flow of altered basalt a } \\
\text { few in. to } 40 \mathrm{ft} \text { thick about } 980 \mathrm{ft} \text { above base. }\end{array}$ \\
\hline PRECAM & RIAN & $\begin{array}{l}\text { Big Cottonwood } \\
\text { formation }\end{array}$ & $1,675+$ & $\begin{array}{l}\text { Phyllitic shale and medium- to coarse- } \\
\text { grained quartzite, both olive-green to } \\
\text { brown; lens of brown-weathering fine- } \\
\text { grained dolomitic limestone exposed in } \\
\text { NW1/4NE1/4 sec. } 3 \text {, T. } 10 \mathrm{~S} \text {., } \mathrm{R} .3 \mathrm{~W} \text {. Base } \\
\text { of formation not exposed in quadrangle. }\end{array}$ \\
\hline
\end{tabular}


The Precambrian rocks are correlated on the basis of color, lithologic characteristics, and stratigraphic position with the Big Cottonwood formation of the central Wasatch Range (Crittenden, Sharp, and Calkins, 1952, p. 3-4). The base of the Big Cottonwood formation is not exposed in the East Tintic Mountains, but elsewhere in northcentral Utah the Big Cottonwood and equivalent rocks unconformably overlie gneiss and schist of early Precambrian age, and disconformably underlie either tillite, quartzite, and argillite of late Precambrian age, or the Tintic quartzite of Early Cambrian age.

The Paleozoic rocks are typical of the miogeosynclinal deposits that are widespread in the eastern part of the Basin and Range province. In the East Tintic Mountains, their total thickness exceeds 25,000 feet, of which 11,000 feet or more is exposed in the Tintic Junction quadrangle. Limestone and dolomite constitute considerably more than half of these rocks; quartzite and sandstone are next in abundance, and shale is least abundant. The limestone and dolomite are commonly argillaceous, and many contain scattered sand grains and interbedded quartzite and sandstone.

In the vicinity of the intrusive rocks and ore deposits of the Tintic district, several stratigraphic units of Paleozoic age, notably the Bluebird and Cole Canyon formations and parts of the Fitchville formation, are wholly or largely dolomite, whereas locally in the northern and northeastern parts of the quadrangle, several miles from the nearest known are bodies, these same units contain conspicuous beds of limestone or ore limestone throughout. Except for the Deseret limestone, the other sedimentary rock units display fairly consistent lithologic characteristics throughout the quadrangle; in contrast, the Deseret limestone contains much more sandstone and sandy limestone in the northwestern part of the map area than in the northeastern part.

The igneous rocks are chiefly intrusive bodies and extrusive lavas and tuffs of middle Eocene age (Muessig, 1951, p. 234; Morris, 1957, p. 29-30), but they also include a flow of dark-red to greenish-gray amygdaloidal basalt intercalated in quartzite conglomerate about 980 feet above the base of the Tintic quartzite of Early Cambrian age.

The predominant extrusive rocks are units of the Packard quartz latite. The principal exposure of these rocks, near Packard Peak from which the formation was named, constitutes the westernmost edge of an extensive blanket of quartz-bearing lavas that covers the north-central part of the Eureka quadrangle. The Packard is the older of two closely related series of volcanic rocks, and in the Allens Ranch, Eureka, and Tintic Mountain quadrangles it is overlain by the Laguna Springs latite, which consists of tuffs, flows, agglomerate, and allied rocks. 
The principal intrusive rocks are a dike and stock of quartz monzonite and the western part of a somewhat larger stock of monzonite. Tower and Smith (1899, p. 635-638) originally described the quartz monzonite as quartz porphyry and named it the Swansea rhyolite from exposures near the Swansea mine. In a later study (Morris, 1957, p. 34) this rock was designated the Swansea quartz monzonite. The larger body of monzonite was named the Silver City stock by Loughlin (Lindgren and Loughlin, 1919, p. 64) from exposures near Silver City in the west-central part of the quadrangle. Near the Swansea mine, short apophyses of monzonite of the Silver City stock cut the Swansea quartz monzonite, and near the small reservoir southwest of Mammoth, the monzonite displays a chilled contact against equigranular quartz monzonite, establishing the monzonite as the younger rock. The quartz monzonite is nearly identical in chemical and mineralogical composition with the Packard quartz latite and thus is probably its intrusive equivalent. The monzonite of the Silver City stock is similarly comparable to the Laguna Springs latite.

A plug of reddish andesite (latite?) breccia is reported by Paul Billingsley (M. D. Paine, oral communication, 1956) to cut the Cole Canyon, Opex, and Ajax formations on the 1700-foot level of the Sacramento mine several hundred feet northwest of the shaft. This plug does not crop out, and a careful search of the dump of the inactive mine failed to yield any of this igneous rock for study and identification.

The postrolcanic deposits consist of thick accumulations of valley fill and lacustrine sediments in the intermontane basins and relatively thin accumulations of talus, colluvium, alluvium, and similar materials in upland areas. These deposits are all postore in age and are not important to the study of the mineral deposits except as they locally conceal ore-bearing or hydrothermally altered rocks. Boundaries between the three postvolcanic formations differentiated on the geologic map (pl. 1) were taken chiefly from aerial photographs after road and railroad cuts and scattered exposures along gullies and stream channels had been carefully examined. Weathered surfaces of the deposits closely resemble each other, and the boundaries shown should be considered only approximate.

The oldest of the postvolcanic deposits is provisionally correlated with the Salt Lake formation of Pliocene age. These deposits are conspicuously exposed east and west of Boulter Summit and constitute the dominant exposures southwest of Tanner Creek. Similiar deposits undoubtedly underlie fan gravels and alluvium of Quaternary age northeast of Tanner Creek. The log of a well drilled by the 
Union Pacific Railroad Co. at Tintic Station (Herbert Waite, written communication, 1958) shows 515 feet of gravel and alluvium overlying yellow clay, white and gray "lime rock," and volcanic gravel which are characteristic of the Salt Lake(?) formation.

The partial section of the Salt Lake(?) formation that crops out in the Boulter Summit area is divisible into a lower unit of moderately well indurated marly limestones and bentonitic tuffs and an upper unit of semiconsolidated gravel-streaked silt; both units are faulted and tilted. The age of the lower unit is estimated by I. G. Sohn (written communication to H. D. Goode, 1955) to be early Pliocene or older, but Sohn cautions that this age may not be reliable (Morris, 1957, p. 28). Neither the base nor the top of the formation is exposed at any place near the East Tintic Mountains.

The beds of the Salt Lake(?) formation near Devil and Death Creeks and throughout a large area west and south of the quadrangle are beveled by a dissected pediment surface that slopes southeast at $3^{\circ}$ to $5^{\circ}$. This surface is covered locally by patchy deposits of gravel composed chiefly of subangular and subrounded fragments of Precambrian rocks derived mainly from the West Tintic Mountains, the range that forms the west boundary of Tintic Valley. Owing to its irregular distribution and to the absence of well-defined contacts, this gravel is not shown separately on the geologic map (pl. 1).

The alluvial fans that extend westward from the East Tintic Mountains form a broad linear bajada that overlaps the tilted beds of the Salt Lake(?) formation. Individual fans retain their original topographic characteristics and therefore are of Pleistocene age. In other parts of the range, similar fans are notched by the shoreline of ancient Lake Bonneville and are overlain by lacustrine gravel, sand, and silt deposited in Iake Bonneville during the Wisconsin glacial stage; the presence of these overlying sediments indicates that the fans had almost achieved their present size and form prior to late Pleistocene time.

The youngest deposits are Recent alluvium along narrow floodplains incised into older fan gravels or covering broad areas of bedrock where slopes flatten near the junctions of stream channels.

\section{STRUCTURE}

The external form of the East Tintic Mountains strongly suggests an origin through relatively simple block faulting of large magnitude, but the internal structures record a moderately complex history of crustal movements that considerably antedate the formation of the range block. The oldest recognized structural events have resulted in several disconformities, the most important of which are between the 
Big Cottonwood formation and the Tintic quartzite, and between the Opohonga limestone and the Fish Haven dolomite. A third disconformity may separate the Victoria formation and the Pinyon Peak limestone. The structural disturbances resulting in these disconformities, and probably others not as readily identified, were apparently broad gentle upwarps, for the strata above and below the disconformities only rarely show measurable angular discordance.

The dominant structures affecting the prevolcanic rocks of the East Tintic Mountains are a series of north-trending, north-plunging asymmetrical anticlines and synclines of great width and amplitude. These folds are cut by several types of faults including thrust and transcurrent faults that were formed at approximately the same time as the folds, and by normal faults, chiefly transverse to the folds, that were formed somewhat later. The age of the principal orogenic movements that produced the folds, thrust faults, and transcurrent faults has been determined from the work of Spieker $(1946$, p. 149-156) in the Wasatch Mountains and Wasatch plateau to be late Late Cretaceous, although the first orogenic disturbances may have originally taken place between Late Jurassic and early Late Cretaceous time. The transverse normal faults are older than the volcanic rocks and were probably formed during the latest Cretaceous or the Paleocene.

Of considerable economic importance is a system of generally northtrending fissures and faults of small displacement that are occupied by narrow veins in the igneous rocks and appear to have been used as channelways by the solutions that deposited the replacement ore bodies in the sedimentary rocks in the Eureka quadrangle. These fissures and faults are obviously younger than the larger stocks, but they appear to be the principal structural control for the late preore monzonite dikes and plugs in the East Tintic mining district, and therefore they are probably middle or early late Eocene in age.

The youngest major structural features recognized in the East Tintic Mountains are normal faults of the Basin and Range fault system; they are part of a regional fault system that Nolan (1943, p. 183) believes first formed in early Oligocene time, or earlier, and has been intermittently active until the present. The general form and outline of the East Tintic Mountains are attributed to displacement and slight rotation chiefly along a zone of these faults at the west edge of the range. Except in the northwest corner of the Tintic Junction quadrangle, however, most of the Basin and Range faults are either unrecognizable where they cut unconsolidated sediments, or they are concealed by alluvium. 


\section{FOIDS}

The southernmost exposed part of the western anticline of the range, the North Tintic anticline of Lindgren and Loughlin (1919, p. 274), extends into the northern and eastern parts of the Tintic Junction quadrangle. This fold is best known from exposures in the Boulter Peak and Allens Ranch quadrangles, where it has a width of at least 10 miles and an amplitude of more than 17,000 feet (Disbrow, 1961; Proctor and others, 1956). The axial zone is mostly concealed by alluvium in Tintic Valley and Van Wagoner Canyon, but the crest is exposed in sec. 27 , T. 9 S., R. 3 W., near the north edge of the quadrangle. In this area the fold trends nearly due north and plunges about $20^{\circ} \mathrm{N}$. The beds on the western limb of the anticline have an average westerly dip of $35^{\circ}$ but generally range in dip from a few degrees to $65^{\circ}$. The beds on the eastern limb are locally vertical or overturned, but the average dip is about $75^{\circ} \mathrm{E}$. The axial plane is probably inclined about $60^{\circ} \mathrm{W}$.

The crest of the North Tintic anticline is about $31 / 2$ miles west of the trough of the adjacent Tintic syncline, which is exposed in the Eureka quadrangle. No analogous syncline is recognized west of the North Tintic anticline, but such a structure may be concealed by sedimentary deposits in the valleys west of the Tintic Junction and Boulter Peak quadrangles.

Several minor anticlines and synclines are present in the Tintic quartzite in the north-central part of the quadrangle a mile or so west of the crest of the North Tintic anticline. These subsidiary folds die out within a few hundred feet along their strike, and they appear to have formed in response to local forces resulting from the asymmetric development of the main fold.

\section{THRUST FAULTS}

Although thrust faults of moderate magnitude are common in other parts of the East Tintic Mountains, only two small faults of this type are exposed in the Tintic Junction quadrangle. The largest is the Bradley thrust, named from the Bradley mine in the E1/2 sec. 2, T. 10 S., R. $3 \mathrm{~W}$. This fault strikes approximately N. $10^{\circ} \mathrm{W}$. and dips east at a moderate angle. The upper plate of the Bradley thrust is less than half a mile wide and is bounded by two east-trending tear faults. One or more subsidiary thrusts also cut the upper plate. Displacement on the main thrust plane brings the Ajax dolomite and Opohonga limestone over the upper part of the Cole Canyon dolomite; this relation indicates a horizontal separation of 400 to 1,100 feet. The movement of the upper plate was relatively westward in contrast to the 
relative eastward movement of the upper plates of the larger thrust faults exposed in other parts of the range.

A steep thrust similar to the Bradley thrust, but smaller, crops out about 2,000 feet north of the Van Wagoner mine. This small fault cuts out most of the conglomerate zone at the base of the Tintic quartzite.

\section{TRANSCURRENT FAULTS}

The transcurrent faults, which may be best understood if the adjoining Boulter Peak, Allens Ranch, and Eureka quadrangles are studied together with the Tintic Junction quadrangle, form a conjugate system of northeast- and northwest-trending fractures that cut the axes of the major folds at angles of $25^{\circ}$ to $55^{\circ}$. Nearly all these fractures dip steeply south, but some are vertical and others dip north. The dominant displacement on most of the fractures is horizontal or nearly so, but the southeast or southwest sides of many show evidence of relative downward movement. In general, the northeast-trending faults have greater displacements than the northwest-trending faults, but, with the possible exception of the Tintic Prince and the Beck faults, the displacements on the northeast-trending faults diminish toward the west edge of the East Tintic Mountains, where several of them terminate against, or are cut off by, northwest-trending faults. The displacement on the Tintic Prince, Beck, and perhaps one or two other northeast-trending faults is largely the result of horizontal movement following the main period of folding, but much of the apparent horizontal displacement on other northeast faults is the result of differential folding and faulting of the beds on the two sides of the fault plane. The northwest-trending faults appear to have originated contemporaneously with the northeast faults as shear fractures, but within the Tintic Junction quadrangle the principal displacement on most of the faults of the northwest-trending group is probably vertical; however, it is almost impossible to determine the actual type of displacement on those faults that do not cut fold axes.

\section{TINTIC PRINCE FAULT}

The fault of largest displacement recognized in the East Tintic Mountains is named from the Tintic Prince mine near the center of the north boundary of the quadrangle. This fault consists of several parallel strands that divide and rejoin, especially near a conspicuous bend of the fault zone a short distance north of the quadrangle boundary. In the Tintic Prince mine area the main displacement apparently took place on closely spaced strands of the fault exposed on the quartzite spur on the east side of Iron Canyon opposite the portal of the Tintic Prince adit. These strands are marked by wide zones 
of breccia weakly stained by iron and manganese oxides. The trace of the principal fault plane is also exposed on the low rounded hill on which U.S. Mineral Mounment 9 is located. South of this hill the trace of the main strand is concealed, although the fault exposed on Round Knoll may be the southwesternmost exposure of this strand. The fault whose remarkably straight trace is exposed on the low spur of Tintic quartzite that forms part of the west side of Iron Canyon is not marked by wide breccias and does not seem to be of the same magnitude as the main strand.

The average strike of the Tintic Prince fault in the Tintic Junction quadrangle is about N. $27^{\circ} \mathrm{E}$. A short distance north of the quadrangle boundary, however, the strike swings to N. $45^{\circ} \mathrm{E}$. The dip is not accurately known, but the relation of fault trace to topography in the Boulter Peak quadrangle indicates that the fault plane probably dips steeply southeast. Exposures in the Tintic Junction quadrangle are not suitable for a close estimate of the magnitude and direction of displacement on the Tintic Prince fault. Disbrow (1961) estimates 5,000 to 7,000 feet of right-lateral strike slip and about 3,000 feet of dip slip at the axis of the North Tintic anticline in the Boulter Peak quadrangle. West of the anticlinal axis, some of this displacement is distributed on other faults that intersect the Tintic Prince fault at acute angles, but most of it is probably on the main-fault plane.

\section{PAXMAN FAULT}

The Paxman fault, named from exposures near the Paxman shaft in the Eureka quadrangle, cuts the east limb of the North Tintic anticline about midway between Eureka Gulch and Packard Peak. It is conspicuously exposed where it crosses the ridge northwest of the Retribution mine and on Bluebird Spur, but along much of its strike it is concealed by talus and alluvium. Between Bluebird Spur and the quadrangle boundary the average strike of the Paxman fault is N. $54^{\circ}$ E., and the nearly straight course of the fault trace across irregular topography indicates that the fault plane dips steeply southeast or is vertical. West of Bluebird Spur the Paxman trends nearly south for about 2,000 feet, but, a short distance before it is lost beneath the alluvium at the edge of the range, it swings more westward and apparently attains a strike of about $\mathrm{N} .40^{\circ} \mathrm{E}$.

An offset of steeply dipping segments of the Ajax dolomite exposed near the east boundary of the quadrangle indicates about 900 feet of right-lateral horizontal separation parallel to the fault trace, but the relative amounts of strike slip and dip slip are not known. West of Cole Canyon, the lateral separation is greatly reduced by down-faulting of the block bounded by the Jenny Lind, Paxman, and Nassau faults. 


\section{BECK FAULT}

The Beck fault is named from its exposures underground in the Bullion Beck mine in the Eureka quadrangle where large replacement-type ore bodies were mined adjacent to it. In the Tintic Junction quadrangle, the trace of the Beck fault is partly concealed by alluvium along the south side of Eureka Gulch, but a short segment is exposed on the low spur northwest of the General Logan mine. At this point the fault brings Ajax dolomite against Cole Canyon dolomite. The fault is also exposed for a considerable distance southwest of the Evans mine, where the Bluebird dolomite and adjacent formations in the northwestern block are faulted against the Ophir formation and the upper part of the Tintic quartzite in the southeastern block. The fault trace is especially conspicuous near the crest of the ridge south of Eureka Gulch where brecciated Tintic quartzite forms both walls. The steeply dipping beds adjacent to the fault in all these exposures have been dragged nearly parallel with the fault plane, and many have been overturned. In railroad cuts near the General Logan and Evans mines, the fault is marked by a wide zone of hydrothermally altered breccia cut by several fault strands that are traceable for only short distances.

The average trend of the Beck fault is N. $37^{\circ} \mathrm{E}$.; the dip is mainly vertical, but where the Beck is exposed on the 1,100-foot level of the Evans mine, the dip is steeply south.

In contrast to the right-lateral displacement on most of the northeast-trending faults, the displacement on the Beck fault is left lateral. Northeast of the California fault the minimum horizontal separation on the Beck fault is about 1,800 feet; southwest of the California fault the separation may be greater but cannot be definitely determined because of pronounced drag. Nearly horizontal mullion structures, some of which are several feet deep, on the walls of the Beck fault underground in the Evans mine and in the Chief No. 1 mine in the Eureka quadrangle indicate only lateral movement on the fault plane.

\section{CENTERNIAI FAUIN}

The Centennial fault, named from the Centennial Eureka mine in the Eureka quadrangle, is exposed for a strike length of only 1,800 feet in the Tintic Junction quadrangle, but it has been followed for 2 miles or more at the surface and underground in the Eureka quadrangle. Throughout most of its course the Centennial fault is approximately parallel with the Beck and East Beck faults, which are about half a mile northwest of it, but in the Tintic Junction quadrangle the Centennial fault diverges from this parallelism, striking about N. $25^{\circ}$ E. at the quadrangle boundary and about N. $20^{\circ}$ E. at the southernmost exposure of the fault. The fault is almost vertical in the Tintic Junc- 
tion quadrangle, but in the Eureka quadrangle the dip ranges from $37^{\circ} \mathrm{SE}$. to $60^{\circ} \mathrm{NW}$.

The steeply dipping beds on the northwest side of the Centennial fault near the east edge of the Tintic Junction quadrangle and in the western part of the Eureka quadrangle have been shifted about 600 feet, relatively to the southwest. Farther southwest, however, the beds are displaced about 75 feet in the opposite direction. This discrepancy may be the result of overturning and drag folding of the beds southeast of the fault, or more likely, the result of movement on strike faults which cut out beds in the Teutonic limestone northwest of the fault.

\section{BLACK CANYON FAULT}

The Black Canyon fault is mostly concealed by alluvium in upper Black Canyon in the north-central part of the quadrangle but is exposed for a short distance in the $\mathrm{N}_{1} / 2 \mathrm{SE} 1 / 4$ sec. 32 , T. 9 S., R. $3 \mathrm{~W}$. where the main branch of the New Bullion fault terminates against it and greatly diminishes the displacement on it. The Black Canyon fault trends approximately N. $45^{\circ}$ E. and dips steeply northwest. Although its northeast trend is similar to that of the strong, predominantly strike-slip faults, the displacement on the Black Canyon fault in the Tintic Junction quadrangle is most logically attributable to relative downward movement of about 1,400 feet on the northwest side. However, the fault may have originated as a shear fracture that later became a dip-slip fault.

\section{MINERS CANYON FAULT}

The Miners Canyon fault is named from Miners Canyon in the Boulter Peak quadrangle. In the Tintic Junction quadrangle it is prominently exposed in the NE $1 / 4$ sec. 31 , T. 9 S., R. $3 \mathrm{~W}$., where it crosses a high ridge a short distance south of the quadrangle boundary. From this point it crops out nearly continuously for $11 / 2$ miles farther southeast; it has an average strike of about N. $45^{\circ} \mathrm{W}$., and the dip is apparently vertical. Near the south line of sec. 32 , T. 9 S., R. 3 W., a northeast-trending fault terminates against the Miners Canyon fault in nearly a right-angle intersection. Northwest of this intersection, beds on the southwest side of the Miners Canyon fault are down approximately 2,500 feet relative to beds on the northeast side. Southeast of the intersection the direction of displacement is reversed: the beds on the northeast side are down a few hundred feet relative to those on the southwest side.

\section{NEW BULLION FAULT}

The New Bullion fault is named from the New Bullion mine in the southern part of the Boulter Peak quadrangle. In that area, Disbrow 
(1961) mapped the fault as trending N. $60^{\circ}$ to $85^{\circ} \mathrm{W}$. and dipping $35^{\circ}$ to $45^{\circ} \mathrm{SW}$; however, at the quadrangle boundary the fault turns southward and attains an average strike of N. $5^{\circ} \mathrm{W}$. and a nearly vertical west dip. Half a mile south of the north boundary of the Tintic Junction quadrangle the fault divides into two strands: the main strand turns southeastward and terminates against the Black Canyon fault, and the minor strand, which maintains the southerly strike, terminates at a focus of faults about 1,600 feet south of the point of division.

Relative displacement on the New Bullion fault in the Tintic Junction quadrangle is reverse: the east side is down about 500 feet in contrast to about 2,000 feet of normal displacement-southwest side down - at the point of maximum displacement on the fault half a mile north in the Boulter Peak quadrangle. This wide variance in the amount and type of displacement is probably the result of independent movement of segments of the New Bullion fault that lie between northeast-trending faults that terminate against the New Bullion fault in both quadrangles.

\section{FREMONT FAUTT}

The Fremont fault is exposed nearly continuously between Fremont Canyon, from which it is named, and the north boundary of the quadrangle near Hannifin Peak. It strikes about N. $45^{\circ} \mathrm{W}$. and dips $70^{\circ}$ to $75^{\circ} \mathrm{SW}$., cutting transversely across steeply dipping beds on the east limb of the North Tintic anticline. Displacement is left lateral; the indicated horizontal separation parallel to the fault trace is 2,200 to 3,000 feet. The relative amounts of strike slip and dip slip are not known, but fault drag suggests that displacement was chiefly. horizontal.

\section{RFD HILL FAULT}

The Red Hill fault is named from its inferred position at the northeast base of Red Hill in the north-central part of sec. 11, T. 10 S., R. 3 W. This fault is largely concealed by alluvium in Bradley Basin, but is readily traced where it cuts the Tintic quartzite in secs. 2 and 3 , T. 10 S., R. 3 W. The almost straight course of the fault across the high ridge of quartzite indicates that the fault plane is nearly vertical; the average strike is $\mathrm{N} .53^{\circ} \mathrm{W}$. The steeply dipping Dagmar dolomite on the northeast side of the fault in Bradley Basin has been shifted about 600 feet relatively to the southeast. In contrast, the basalt flow in the steeply dipping Tintic quartzite on the same side of the fault near its northwesternmost exposure is offset about 300 feet to the northwest. These relations may possibly be explained by early left-lateral strike slip on the Red Hill fault, followed by later movement that relatively downdropped the block bounded by the Red Hill fault, the 
Dead Horse fault, and the steep northeast-trending fault that is inferred to underlie alluvium in the lower part of Bradley Canyon.

\section{JENNY LIND FAULT}

The Jenny Lind fault, named from Jenny Lind Canyon, extends from the Dead Horse to the Paxman fault cutting obliquely across Jenny Lind Canyon and Teutonic Ridge. The straight trend of the fault across Teutonic Ridge indicates that it is vertical or nearly so in this area, but exposures west of Jenny Lind Canyon suggest a steep dip to the southwest. The strike averages N. $62^{\circ} \mathrm{W}$. Displacement seems to be chiefly dip slip the beds on the southwest side of the fault being down about 1,675 feet relative to those on the northeast side; however, the general trend of the Jenny Lind fault and its relation. to the Paxman fault suggest that it may have originated as a shear fracture along which dip-slip movement of somewhat greater magnitude later took place.

\section{GEMINT FAUTT}

The Gemini fault, so named from its exposures underground in the Gemini mine in the Eureka quadrangle, is largely concealed by alluvium except near the Black Warrior mine in Cole Canyon. In this area the approximate position of the fault is readily determined by the displacement of the Emerald member of the Ajax dolomite, but the breccias associated with the fault are healed by secondary dolomite and the fault zone is not conspicuous. The Gemini fault strikes $\mathrm{N}$. $60^{\circ}$ to $80^{\circ} \mathrm{W}$. and $\operatorname{dips} 50^{\circ}$ to $60^{\circ} \mathrm{SW}$. Beds on the northeast side are displaced 150 to 300 feet to the northwest relative to those on the southwest side, as a result of either reverse dip slip of 850 to 1,700 feet or, more likely, the comparatively smaller amount of strike slip indicated by the horizontal separation.

Although the Gemini and Jenny Lind faults are separated by the Paxman fault, they are nearly colinear at the surface and have been considered to be the same general structural feature. However, the two faults are not offset by the Paxman fault; the Jenny Lind dips more steeply than the Gemini fault, and the apparent lateral displacement on them is in opposite directions. This relationship suggests that the Jenny Lind and Gemini faults formed in response to different forces, the Gemini probably developing chiefly as a result of compressive deformation and the Jenny Lind chiefly as a result of tensional deformation.

\section{NASSAU FAULT}

The Nassau fault is here named from the Nassau claim, which lies a short distance north of the entrance to Eureka Gulch. The fault is exposed for only slightly more than a quarter of a mile on the north- 
west side of the Paxman fault between the southern end of Teutonic Ridge and Jenny Lind Canyon. It is vertical or nearly so and strikes $\mathrm{N}$. $70^{\circ} \mathrm{W}$. The displacement on this fault is probably a combination of both early left-lateral strike slip and later vertical dip slip of somewhat greater magnitude, which downdropped the beds on the northeast side relative to those on the southeast side. The horizontal separation of the lower contact of the Ophir formation north and south of the fault is about 725 feet.

The group of short east- and southeast-trending faults that cut Bluebird Spur near the intersection of the Nassau and Paxman faults may have formed at approximately the same time as the strike-slip movement on the Nassau fault, and they may be displaced parts of the same fault zone. As regional east-west compression increased, two of these faults became tear faults related to the short north-trending reverse fault that cuts out the Bluebird dolomite and adjacent parts of the Herkimer limestone and Cole Canyon dolomite on the west side of Cole Canyon. Other steep reverse faults between the Ophir formation and the Teutonic limestone, and between the Tintic quartzite and the Ophir formation in the same area, probably resulted from the same compressive forces.

\section{CALTFORNIA FAULT}

The California fault takes its name from the California stope, which is near it in the Centennial Eureka mine in the Eureka quadrangle. The fault is exposed in the Tintic Junction quadrangle near the General Logan shaft and apparently terminates against the Beck fault. The average strike of the fault is $\mathrm{N} .60^{\circ} \mathrm{W}$, and the dip is steep to the south. The near vertical beds on the northeast side are offset approximately 350 feet northwest relative to those on the southwest side. The orientation of minor drag folds indicates that the movement was chiefly horizontal and that possibly some later vertical displacement. north side relatively down, took place.

\section{TRANSVERSE NORMAL FAULTS}

Two east-trending normal faults of large displacement that are younger than the transcurrent faults but older than the volcanic rocks are exposed in the East Tintic Mountains, most conspicuously in the Eureka quadrangle (Morris, 1957, p. 50-51). The largest of these faults is exposed in the Tintic Junction quadrangle in sec. 11, T. 10 S., R. $3 \mathrm{~W}$. The other may underlie Quaternary alluvium in Mammoth Gulch, or it may have been engulfed by the intrusive rocks south of it. The exposed fault, which has been given the name Dead Horse fault in unpublished geological reports and maps (R. C. Gebhardt, written communication, 1953) but which is correlated with the Homansville 
fault of the Eureka quadrangle, strikes about N. $87^{\circ}$ E. and dips very steeply north. Displacement is normal, north side relatively down, and increases from 1,300 feet or less in the western part of its exposure to more than 1,700 feet in the eastern part. Prior to the eruption of the Packard quartz latite, the trace of the Dead Horse fault was the site of a deep eastward-sloping valley that became partly filled with coarse gravel and later with lava.

\section{POSTVOLCANIC MINERALIZED FAULTS AND FISSURES}

The veins that cut the larger instrusive bodies occupy fissures and faults of small displacement. In the Tintic Junction quadrangle, these fractures are best exposed near Silver City, where some of the veins were mined during the earliest phases of mining activity in the East Tintic Mountains. The strike of these features is generally northward, but ranges from about N. $15^{\circ} \mathrm{W}$. to N. $50^{\circ} \mathrm{E}$. Most of the mineralized faults and fissures $\operatorname{dip} 70^{\circ}$ to $80^{\circ} \mathrm{W}$. or NW., but some have flatter dips, others are vertical, and a few dip east. The maximum displacement on the faults is not confidently known but probably does not exceed a few hundred feet.

The mineralized fissures that cut the sedimentary rocks, especially in the adjacent Eureka quadrangle, presumably are related to these fractures, although the fissures commonly follow bedding plane faults for long distances.

\section{LATE NORMAI FAULTS}

The truncation of major geologic structures at the west edge of the East Tintic Mountains and the abrupt topographic differences between the range block and the valley indicate the presence of late normal faults of the Basin and Range fault system. The principal exposed fault in this group crops out in the northwestern part of the quadrangle; it trends N. $57^{\circ} \mathrm{W}$. and dips about $45^{\circ} \mathrm{SW}$. The hanging wall is semiconsolidated fanglomerate of Pleistocene age, and the footwall is limestone of Mississippian age; to the southeast the boundary between bedrock and alluvium is also generally aligned with this fault. Inasmuch as the exposed part is approximately parallel to the northwest-trending transcurrent faults, this fault may have originally been a shear fracture that was reactivated during the formation of the Basin and Range faults. A gravity survey of this general area made by K. L. Cook and J. W. Berg, Jr. (1961, p. 85) indicates a total gravity relief of 20 milligals across the fault zone in the northern part of Tintic Valley. According to D. R. Mabey (oral communication, 1957), the gravity data suggest that more than 7,200 feet of valley-fill deposits underlies the area just north of Knight. 


\section{MINERAL DEPOSITS}

The mineral deposits thus far discovered in the Tintic Junction quadrangle may be subdivided into three general groups: (a) narrow veins of pyritic silver-lead and copper ores, chiefly in intrusive rocks, (b) small replacement deposits of lead, zinc, copper, and managanese minerals in the Paleozoic rocks, and (c) deposits of nonmetallic materials including quartzite, halloysite, limestone, and road metal. The most important deposits are the veins. Their total production is unknown, but the Swansea mines were among the earliest producing mines in the Tintic district, and Heikes (in Lindgren and Loughlin, 1919, p. 105) reports that they were still shipping ores 40 years after discovery. The total gross production of ore from veins in the Tintic district has been estimated at $\$ 12$ million (Cook, 1957, p. 60). Approximately one-sixth to one-eighth of this total may be credited to mines in the Tintic Junction guadrangle. This value is small, however, in comparison with the value of ores from the extensive replacement ore bodies in the Eureka quadrangle.

\section{VEINS}

The pyritic silver and base-metal veins cut both the Swansea quartz monzonite and the monzonite of the Silver City stock. The veins range from knife edge seams to well-defined structures about 10 feet thick; most are no more than a few hundred feet long, but the Swansea vein zone has been mined through a horizontal distance of about 2,000 feet. The longer vein zones consist of individual veins a few tens of feet to several hundred feet long arranged en echelon in zones of parallel multiple fractures 5 to 20 or more feet thick; as a general rule, the wider mineralized parts of the veins do not overlap for more than a few feet. Several of the larger veins in the Swansea zone, are connected by linking or cross veins. However, the main veins diminish to barren fractures within a short distance beyond the point of juncture.

Short spur veins, which branch downward or upward from the larger veins, have been described by Tower and Smith (1899, p. 758) chiefly from the Swansea vein zone. They noted one such vein on the 300 -foot level of the original Swansea mine about 25 feet west of the main vein. At this point the spur vein is vertical, but within less than 100 feet above the level it joins the main vein, which dips east in the area of the intersection. The largest spur vein recognized in the Swansea area is followed by the Four Aces shaft. According to Lindgren and Loughlin $(1919$, p. 255-256), this vein branches off the main Swansea vein at the 600-foot level of the South Swansea mine and extends upward to the east at a $60^{\circ} \mathrm{dip}$, and the main vein 
slopes $80^{\circ}$ upward to the west to the 400 -foot: level. The combined vein below the junction as well as the main vein above the 400 -foot level dip $80^{\circ}$ to $85^{\circ} \mathrm{W}$.

The principal primary ore minerals of the veins are pyrite and galena, but enargite, sphalerite, and arsenopyrite are also important in some veins. The gangue minerals are quartz, barite, and the minerals of the wall rocks, which are almost completely replaced by fine-grained quartz and sericite. The valuable metals are silver, lead, copper, minor zinc, and gold. The silver content is highest, as a general rule, in the galena and enargite, but some of the pyrite in the Swansea veins was sorted and shipped as silver ore (Tower and Smith, 1899, p. 759).

The vein minerals are described in earlier reports (Tower and Smith, 1899, p. 758; Lindgren and Loughlin, 1919, p. 255) as being arranged in bands an inch or so to several feet thick. These bands consist predominantly of quartz, pyrite, or galena. The bands whose centers are marked by vugs appear to lie along original fractures and are separated by vertical sheets of altered wallrocks, but the broader bands apparently have filled open fractures and have also replaced intervening slabs of country rock. Some bands consist of quartz and massive or pyritohedral pyrite in nearly equal amounts; others are entirely pyrite. Galena is concentrated in less common lenticular bands; some of the galena-rich bands contain pyrite or quartz and others are nearly pure. Enargite is common only in veins that contain considerable barite; it occurs in coarsely granular masses that are intergrown with pyrite at the margins of the shoots.

The ore shoots of the veins are not sharply defined and merge gradually with the quartz-pyrite vein filling. They are lens shaped and lack a clearly defined rake. The largest ore shoot in the Swansea Consolidated mine is shown by Lindgren and Loughlin (1919, fig. $45, \mathrm{pl} .3$ ) to have been stoped continuously from a point within 40 feet of the surface to a maximum depth of about 800 feet and through a maximum horizontal distance of 900 feet between points 500 feet north of the original Swansea shaft and 100 feet north of the Swansea Consolidated shaft. The general shape of the stoped area projected to the plane of the vein is that of the letter $T$, the stem of which rakes $35^{\circ} \mathrm{N}$. Smaller ore bodies were mined north and south of the main shoot. One of these ore bodies extended almost continuously along the surface for 600 feet or more and reached a maximum depth of 130 feet.

The primary ores of the veins were sorted into two classes: galenapyrite ore and pyrite ore. According to Tower and Smith (1899, p. 759 ), the galena-pyrite ore averaged 50 ounces of silver to the ton, 20 
percent lead, 30 percent iron, and 15 percent silica. The pyrite ore averaged 25 ounces of silver to the ton, 7 percent lead, 38 percent iron, and 13 percent silica. Lindgren and Loughlin (1919, p. 257), report that 15 shipments of ore from the Swansea Consolidated mine made in 1914 averaged 0.03 ounce of gold and 30.7 ounces of silver to the ton, 12.5 percent lead, 0.26 percent copper, 0.9 percent zinc, 31.0 percent iron, 31.4 percent sulphur, 19.0 percent silica, 2.9 percent speiss (metallic arsenides and antimonides), and 0.5 percent lime.

The oxidized parts of the veins, which extended irregularly to the permanent water table at a depth of 100 to 650 feet, contained ore of considerable value that was mined during the earliest period of activity in the Tintic district. Few data are available on the oxidized ore, for most of it was mined out before the first comprehensive studies of the geology of the district were made in 1897. Early records indicate, however, that it consisted chiefly of iron-stained quartz, limonite, and sandy lead carbonate, locally streaked with thin seams of oxidized copper minerals. Much of the oxidized ore contained several hundred ounces of silver to the ton, but the average grade probably did not exceed 90 ounces of silver to the ton and 40 percent lead, which Tower and Smith $(1899$, p. 759) report to be the average grade of some carbonate ore taken from the South Swansea mine in 1897. The form in which the silver occurred is not known, but reports that native silver was not abundant suggest that it was present chiefly as argentojarosite and cerargyrite. In even the most thoroughly oxidized parts of the veins, some galena remained as small lumps coated with anglesite and cerussite. Most of the smaller veins were exploited only in the oxidized zone, and no attempts were made to mine the lower grade primary ores, chiefly because the pay shoots were small and irregular in occurrence and because pumping large volumes of water was expensive. The oxidized ore first was screened to separate the large lumps of barren quartz and then was reduced to bullion in local furnaces or shipped to custom smelters, some as far as Swansea, Wales (Tower and Smith, 1899, p. 613).

Most of the veins are bordered by selvages of altered rocks, generally ranging from a few inches to 20 feet wide. Within these selvages, overlapping zones of sericitized, sillicified, and argillized rock are recognized. Adjacent to the vein filling, the wallrocks are mainly a quartz-sericite aggregate containing disseminated pyrite. Outward from the vein, sericite diminishes and the rock consists of secondary quartz or jasperoid and some kaolimite, sericite, and residual quartz and orthoclase. In the central part of the argillic zone, secondary. quartz is absent and kaolinite and halloysite dominate, but on the wallrock side of the argillic zone these minerals give way to montmorillonite as the alteration selvage becomes indistinquishable from the 
generally propylitized country rock. Disseminated pyrite is persistent throughout the alteration zones and commonly extends into the least altered country rock. The moderate bleaching and iron staining of the wallrocks at some distance from the veins is largely the result of weathering of this pyrite, but this bleached rock should not be confused with the more strongly bleached argillized rocks closer to the vein wall. . The wallrocks apparently were not altered simultaneously with the deposition of ore in the veins, inasmuch as a few ore shoots have unaltered walls and many barren fissures are bordered by zones of argillized rock.

\section{REPLACEMENT DEPOSITS}

The replacement deposits in the quadrangle consist of scattered small bodies and pockets of ore minerals, most commonly in altered carbonate rocks near faults. Typically these deposits are nonsiliceous and consist of oxidized galena and sphalerite, or enargite; they may or may not contain pyrite in a gangue of secondary dolomite or calcite. Almost invariably the tenor of silver is low and gold is absent. The largest of the deposits did not produce more than a few tons of ore, but they may indicate the presence of concealed ore bodies of possible commercial interest.

The mines and prospects at which occurrences of ore minerals were noted include the Munding (lead), Tintic Prince (lead, zinc, and gold (?), Silver Bell (copper), Dagmar (copper, lead, and zinc), Balhinch (lead), Golden Sunset (lead and copper), and Fields (manganese and zinc). Assayable quantities of gold, silver, and other metals have been reported from other mines and prospects in the sedimentary rocks of the quadrangle, but these reports were not confirmed during the present study.

\section{NONMETALLIC DEPOSITS}

Deposits of nonmetallic commodities in the quadrangle include high-silica quartzite, halloysite clay, limestone and dolomite, cement rock, and gravel. The most important of these commodities is highsilica quartzite produced from the Garrity quarry in the NE1/4 sec. 23 , T. 10 S., R. $3 \mathrm{~W}$. The quartzite is broken, screened, and washed at the quarry site and loaded directly into railroad cars for transportation to a processing plant near Salt Lake City which produces silica brick.

The halloysite clay occurs as a replacement of limestone, tuff, and prelava rubble at the base of the Packard quartz latite half a mile northwest of Packard Peak. The deposit was explored by the Filtrol Corp. in conjunction with the exploration and development of the halloysite deposit at the Dragon mine in the Eureka quadrangle.

The limestone and dolomite, cement rock, and gravel are exploited for local use only. 


\section{LITERATURE CITED}

Cook, D. R., 1957, Ore deposits of the main Tintic district, in Geology of the East Tintic Mountains and ore deposits of the Tintic mining districts: Ctah Geol. Soc. Guidebook 12, p. 57-79.

Crittenden, M. D., Jr., Sharp, B. J., and Calkins, F. C., 1952, Parleys Canyon to the Traverse Range, part of Geology of the Wasatch Mountains east of Salt Lake City, in Geology of the Central Wasatch Mountains, Utah : Utah Geol. Soc. Guidebook 8, p. 1-37.

Disbrow, A. E., 1961, Geology of the Boulter Peak quadrangle, Utah: U.S. Geol. Survey Geol. Quad. Map GQ-141.

Lindgren, Waldemar, and Loughlin, G. F., 1919, Geology and ore deposits of the Tintic mining district, Utah, with $a$ Historical review by V. C. Heikes: U.S. Geol. Survey Prof. Paper 107, 282 p.

Morris, H. T., 1957, General geology of the East Tintic Mountains, Utah, in Geology of the East Tintic Mountains and ore deposits of the Tintic mining districts: Utah Geol. Soc. Guidebook 12, p. 1-56.

Morris, H. T., and Lovering, T. S., 1961, Stratigraphy of the East Tintic Mountains, Utah, with a section on Quaternary deposits by H. D. Gocde: U.S. Geol. Survey Prof. Paper 361.

Muessig, Siegfried, 1951, Eocene volcanism in central Utah: Science, v. 114, no. 2957 , p. 234 .

Nolan, T. B., 1943, The Basin and Range province in Utah, Nevada, and California : U.S. Geol. Survey Prof. Paper 197-D, p. 141-196.

Proctor, P. D., and others, 1956, Preliminary geologic map of the Allens Ranch quadrangle, Utah: U.S. Geol. Survey Mineral Inv. Field Studies Map MF-45, scale $1: 12,000$.

Spieker, E. M., 1946, Late Mesozoic and early Cenozoic history of central Utah : U.S. Geol. Survey Prof. Paper 205-D, p. 117-161.

Tower, G. W., Jr., and Smith, G. O., 1899, Geology and mining industry of the Tintic district, Utah: U.S. Geol. Survey 19th Ann. Rept., pt, 3-F, p. 601-767. 
